\title{
Capital Structure and Financial Performance: A Case of Saudi Petrochemical Industry
}

\author{
Anis ALI ${ }^{1}$, Shaha FAISAL ${ }^{2}$
}

Received: April 30, 2020 Revised: May 17, 2020 Accepted: June 07, 2020

\begin{abstract}
The study investigates and measures the impact of capital structure, profitability and financial performance on the success of the business organization. Capital structure of the business organization refers to the proportion of external funds and internal funds, i.e., debt and equity. In Saudi Arabia, petrochemicals companies are working on equity, but financial performance reflects negative trend for the period 2004 to 2016. The research is based upon secondary data available on the websites of petrochemicals companies of Saudi Arabia. Financial Ratio variability analysis and Trend Indices of financial ratios $\left(\mathrm{TI}_{\mathrm{CBI}}\right)$ measure and compare the financial variability and sensitivity of financial ratios of the business organization. Correlation between Trend Indices $\left(\mathrm{TI}_{\mathrm{CBI}}\right.$ ) of independent variable and dependent variables are to be calculated to know the impact of changes in debt equity on other dependent variables. The results reveal the unexpected performance of petrochemicals companies due to under-utilization of the resources caused by low demand and lower prices of the products governed by some internal and external factors. The study finds that size, demand, cost of production, profitable streams of products, and low cost capital in external funds are the factors responsible for overall growth development of the petrochemicals industry of Saudi Arabia.
\end{abstract}

Keywords: Debt Equity, Profitability, Revenues, Sensitivity Analysis, Capital Structure, Saudi Arabia

JEL Classification Code: P27, C43, L25, L65, M41

\section{Introduction}

Nowadays, profitability and profit determine the success of a business organization engaged in production of goods and services. Profitability is a relative term while profit is an absolute measurement of the outcomes of the business activities. Profit is the integrated result of the profitability and expansion of the business activities. So, profitability defines the degree of utilization of resources of an organization and leads the organization towards the monetary success and

${ }^{1}$ First Author. Assistant Professor, College of Business Administration, Prince Sattam Bin Abdulaziz University, Saudi Arabia. Email: ah.ali@psau.edu.sa; ali.anish82@gmail.com

${ }^{2}$ Corresponding Author. Assistant Professor, College of Business Administration, Prince Sattam Bin Abdulaziz University, Saudi Arabia [Postal Address: P.O Box 165, Al-Kharj, 11942, Saudi Arabia] Email: s.shah@psau.edu.sa; msfaisalq@gmail.com

(c) Copyright: The Author(s)

This is an Open Access article distributed under the terms of the Creative Commons Attribution Non-Commercial License (http://Creativecommons.org/licenses/by-nc/4.0/) which permits unrestricted noncommercial use, distribution, and reproduction in any medium, provided the original work is properly cited. development. In any business, the tradeoff refers to the point where the cost of all resources equals all revenues, while the degree of relationship between revenues and cost of total resources indicates the velocity of profitability that will extend as per the level of business activities.

The capital structure or debt-equity ratio also helps to extend the activity level of the businesses or size of the business. If the cost of capital is lower than the normal rate of return it will positively affect the profit and profitability of the business organization. So, many factors in the business affect the profit and profitability. The polar extremes of business revenues and business expenditures explain the degree of profitability. The degree of profitability governs the absolute amount of profit and varies according to the size and level of the business activities. So, to assess the sufficiency of profit of any business organization, profitability is the base and it further governs the absolute amount of the profit taking into consideration the excess of business revenues over operational expenditures. This paper examines the impact of capital structure or debt-equity ratio on other financial measures and explains the relationship and governance of profitability by the capital composition. 


\section{Literature Review}

Velnamy and Niresh (2012) recommended in their study that top management of all banking firms should make rational financing decisions in order to achieve profitability and competitiveness. They further added that banks should focus on internal sources of financing to enhance their profitability. Nasimi (2016) advocated that an optimal level of capital structure, effective utilization, and allocation of resources is helpful to achieve organizational goals and a level of efficiency in the business organization. Ahmad (2014) explained that there is positive and strong relationship between profitability and capital structure of the business organization. There is a negative relationship between external liabilities and profitability of the businesses. Kumar (2015) found that the capital structure ratio is positively associated with all profitability ratios based on investments. He further explained that there is a positive relationship between debt-to-total-fund ratio and ROE (return on equity) while ROE is negatively correlated with ROCE (return on capital employed) and debt-to-equity ratio.

Subramaniyam (2013) revealed a significant relationship between capital structure and ROCE and insignificant relationship between capital structure and ROE (Return on Equity). Marandu and Sibindi (2016) found strong relationship between ROA (Return on assets) and capital structure in banks. Shah (2015) stated the capital structure of corporation effects profitability favorably and leads towards growth and development of the corporation and finally concluded that there is significant relationship between working capital and firms' performance. Ashvin (2017) revealed in his study that there is a negative relationship between capital structure and profitability of the corporation in petrochemicals industry in India. He further stated that there is a positive relationship between working capital ratio and negative relation between profitability and debtor's turnover ratio. Waweru and Ngugi (2014) explained in their studies that there is a positive relationship between capital structure and profitability of SMEs of Kenya and observed that heavy investments in receivables lower the profitability of the organization. He suggested that there is need to maintain an optimum balance between receivables and inventory holding time.

Rehman et al. (2014) observed that there is a significant relationship between the creditors turnover ratio, debtor's turnover ratio, inventory turnover ratio, debt equity ratio, total assets turnover ratio and net profit margin of petrochemical companies in Saudi Arabia. Abor (2005) observed that short-term debts are more appropriate to finance operational activities of the business in Ghana and their negative relationship between long-term debts and profitability. Further, he explained that Ghanian firms are depending upon the debts of which $85 \%$ is short-term debt.
Merugu Venugopal and Reddy (2016) found that there is no significant positive relationship between capital structure and profitability, market value and wealth of the shareholders' in cement industry in India. Sultan and Adam (2015) found a direct relationship between capital structure and profitability and a negative relationship between capital structure and size of the firm. Shubita and Alsawalhah (2012) advocated that capital structure decision is the crucial decision and equip organization to face the competition. He revealed that there is a negative relationship between capital structure and profitability of the firm. Nguyen and Nguyen (2020) revealed that capital structure has a negative effect on firm performance, while it is stronger in state-owned enterprises and weaker in privately-owned enterprises in Vietnam. There are some other factors, which are responsible for the profitability of the organization, i.e., size of the firm and sales growth.

Dao and Nguyen (2020) found that there is a negative influence of size (bank) on profitability. Nguyen et al. (2020) found that the profitability of the business organization is affected by the firm size, growth rate of sale, working on equity, and age of business organization. The working capital management also plays a vital role in the in profitability enhancement of the business organization. Chisti et al. (2013) explained that there is a negative relationship between debt-to-equity ratio and the profitability of the business organization. They further added that debt-to-assets ratio and interest coverage ratios are positively governing profit earning ability of the organization. Ali and Theeb (2018) studied that there was negativity in operational performance after the global economic recession in the petrochemical sector of Saudi Arabia. He suggested that companies should focus on minimizing cost of production of petrochemicals products. Cheng et al. (2020) noted that the ability of the topclass management and strategy of the business organization positively affects the financial performance.

\section{Research Methods and Materials}

The study is based upon secondary data taken from the websites of the petrochemicals companies of Saudi Arabia. Financial ratios are calculated to know the profitability and capital structure or financial position of the petrochemicals corporations. Financial accounting ratio analysis establishes relationship between two variables from the financial statements of the business organization. Gross profit ratio (G/P R), return on assets (ROA) and return on equity (ROE) measure the profitability while current ratio (CR) and Debtequity ratio (D/E R) measures the short term paying ability and defines the capital structure of the business organization. In this study, debt-equity ratio is to be considered as independent variable while all the profitability (G/P R, ROA, and ROE) and liquidity (CR) measures are to be considered as dependent variables. 
Financial ratio variability analysis measures and compares the variability of ratios logically related to financial statements of the business organization. To get financial ratio variability, correlations among the average financial ratios of petrochemicals companies of Saudi Arabia calculated. Trend indices of financial ratios $\left(\mathrm{TI}_{\mathrm{CBI}}\right)$, which are based on chainbase index numbers, are to be calculated to know the shortterm average movements of the independents and dependent variables.

The average ratios of independent and all dependent variables are to be considered as they are reflecting the average scene of the petrochemicals industry of Saudi Arabia. Chain-based index numbers of all variables (average financial ratios of petrochemical companies) are calculated to get instant impact of dependent variables on dependent variables after establishing correlation between debt-equity ratio and other dependent ratios (gross-profit ratio, return-on-assets, return-on-equity and current ratio). To get financial ratio sensitivity, correlation between trend indices of $\left(\mathrm{TI}_{\mathrm{CBI}}\right)$ of independent variable (debt equity) and dependent variable (profitability, return on assets, return on equity and liquidity) are to be calculated to know the impact of changes of debt-equity ratio on other dependent variables. From the following formula, trend indices can be calculated yearly for independent and dependent variables.

Trend Indices $\left(\mathrm{TI}_{\mathrm{CBI}}\right)=\frac{\text { Current year's Variable } * 100}{\text { Previsous year's Variable }}$

Financial ratio sensitivity analysis also measures the impact of movement of independent variables on dependent variables in short run. In calculation, chain-based index numbers year 2004 is considered as base year and financial data of 2008 and 2009 not considered as it was the global economic recession period (GER).

\section{Results and Discussion}

Analysis of financial data of petrochemical companies is split into two categories, i.e., financial ratio analysis and financial variability analysis.

\subsection{Empirical Results}

\subsubsection{Financial Ratio Analysis}

Following ratios are to be calculated to know the relationship or impact of capital structure (debt-equity ratio) on profitability (gross profit ratio, ROA and ROE) and paying ability (current ratio) of the petrochemicals companies of Saudi Arabia.

\section{Debt- Equity Ratio (D/E R)}

Debt-equity ratio is the relationship of (contractual capital or fixed bearing cost capital) and equity (shareholders' fund). The debt-equity ratio can be calculated from the following formula:

$$
\text { Debt-equity Ratio }(\mathrm{D} / \mathrm{E} \mathrm{R})=\frac{\text { Long }- \text { term debts }}{\text { Owners'equity }}
$$

This ratio explains the methodology or policies of managing funds from external sources (debts) or internal sources (shareholders' fund). The ratio also explains the real proprietary of the shareholders' of companies. The higher debt-equity ratio indicates increased utilization of external funds and enhances the profitability of the organization when the contractual cost of capital is lesser than normal rate of return of the business. Debt-equity ratio also governs the liquidity of the business organization indirectly (Ali \& Haque, 2014). So, debt-equity ratio can also be effective as tool to maintain the liquidity and profitability of the organization. In Saudi Arabia, overall debt-equity ratio of the petrochemicals companies are increasing and companies are adopting the policies of working on equity. SAFCO and TASNEE companies are adopting extreme polar policies of debt-equity (Appendix 1). Average of debt-equity ratio was $70 \%$ before GER and after it was increased by 15 and stood at $95 \%$. Presently, Petrochemical industry of Saudi Arabia is working on equity and debt is more than $120 \%$ of equity capital. NAMA and TASNEE companies' capital structure is extremely utilizing external funds to manage the funds for business activities (Appendix 1).

\section{Profitability Ratio}

A profitability ratio explains the profit earning capacity of the organization and reveals the positivity or negativity of the business activities with the degree of variation. Profitability ratios can be split into two categories, i.e., operational profitability and utilization of resources profitability.

Operational Profitability: Operational profitability is the outcomes of the operational activities of the business organization. Operational profitability reveals the efficiency of production or manufacturing activities of the business organization.

Gross Profit Ratio (G/P R): Gross profit ratio establishes the relationship between the absolute amount of gross profit and net sales of the organization. The gross profit ratio can be calculated from the following formula.

$$
\text { Gross Profit Ratio }(\mathrm{GPR})=\frac{\text { Gross profit*100 }}{\text { Net sales }}
$$


The higher revenue and lower cost of production will create the margin and lead towards the favorable operational profitability (Ali \& Haque, 2014). Average profit earning ability of the petrochemicals industry of Saudi Arabia is diminishing years after year. In the period of four years (2004 to 2007), the average profitability of selected petrochemicals companies was $92.52 \%$, but for the period after four years of the GER (global economic recession) it came down at $51.90 \%$, which is approximately half the average period immediately preceding the GER. Recently, average profit earning capacity of the petrochemicals industry of Saudi Arabia is in negative situation, indicating the lower sales prices, high manufacturing costs and low demands in international market. Profitability of Sipchem Co. was outstanding is the four years preceding the GER, but recently is the highest negative profitability among the petrochemicals industry in Saudi Arabia (Appendix 1).

Utilization of Resources: Utilization of resources reflects how efficiently a business organization is utilizing its resources in the operation of business activities. Utilization of resources can be explained by establishing the relationship between profit and total assets or profit and shareholders fund. So, ROA and ROE are to be calculated to get the efficiency of utilization of total resources or shareholders' fund.

Return on Assets (ROA): Return on total assets establishes a relationship between profit before tax (PBT) and total assets and reveals the efficiency of utilization of total resources of the business organization. The ROA can be calculated from the following formula.

$$
\text { Return on Assets }(\mathrm{ROA})=\frac{\text { Profit before Tax } * 100}{\text { Total Assets }}
$$

The higher ROA indicates the efficient utilization of financial resources and profitable for the business organization (Ali \& Haque, 2014). In Saudi petrochemicals industry, rate of return on total assets was satisfactory before the GER. There was slight slowdown in the ROA after the GER, but recent growth of return on total return in the petrochemicals industry of Saudi Arabia is lower and disappointing. There is need to utilize the resources economically and attempts should be made to enhance the turnover of the petrochemicals companies. Average rate of return on assets (ROA) is lowering continuously as it was $9.75 \%$ and $9.42 \%$ before and after four years of GER. Recently, In Saudi petrochemical industry, average of ROA is at its lowest level (3.64\%) which is lower than cost of capital, probably. ROA of NAMA and TASNEE is either extremely negative or negligible while SAFCO. SABIC and SIIG companies return is satisfactory (Appendix 1).

Return on Equity (ROE): Return on total assets establishes relationship between profit after tax (PAT) and shareholders fund and reveals the efficiency of utilization of investment of real owners of companies. The return on equity can be calculated from the following formula.

$$
\text { Return on Equity }(\mathrm{ROE})=\frac{\text { Profit after Tax } * 100}{\text { Shareholders'Fund }}
$$

The higher ROE is favorable for the business organization and reveals the utilization of the owners' equity favorable (Ali \& Haque, 2014). Return on net worth or shareholders' fund of petrochemicals companies of Saudi Arabia indicates that the companies' return on owners fund is satisfactory since last many years and it indicates that companies are employing external funds to operate their business activities. Average of return on equity or shareholders fund was $32.02 \%$ before GER, while increased after GER and obtained splendid level of return (57.36\%). Recently, return on equity is lowering probably due to low turnover, excess cost of external funds etc. (Appendix 1).

Liquidity: Liquidity refers the paying ability of a business organization. Liquidity establishes relationship between assets and liabilities. The relationship between long term liabilities and total assets reveals the long term paying ability, which is also explained by the debt-equity ratio. In fact the long term paying capacity of the organization indicates the robust financial position of the corporation. So, liquidity refers short time paying abilities to pay out its debts.

\section{Current Ratio (CR)}

Current ratio is the ratio of current assets and current liabilities and scales the short term redemption capacity of the business organization. The current ratio (CR) can be calculated from the following formula.

$$
\text { Gross Profit Ratio }(\mathrm{CR})=\frac{\text { Current Assets }}{\text { Current Liabilities }}
$$

The higher current ratio is the indication of sound short term paying capacity, but signal for blockage of funds in operational activities and explains negativity of utilization of resources (Ali \& Haque, 2014). The liquidity position of the petrochemicals sector of Saudi Arabia is very satisfactory as the average current ratio for the selected petrochemicals companies are more than 2 (Appendix 1). However, another aspect of high liquidity of petrochemicals companies indicates the blockage of funds or underutilization of resources.

\subsubsection{Financial Variability Analysis}

Financial variability analysis refers the volatility of financial variables taken from the financial statements, which are parts of financial reports of the business organization. 
The comparative analysis of the volatility of the inputs and outputs of the financial variables will measure the associated risk. The financial variability analysis can be split into two, i.e., financial ratio variability analysis and financial ratio sensitivity analysis.

\subsubsection{Financial Ratio Variability Analysis}

Financial ratio variability analysis measures the variability of two or more logically interrelated ratios for a given time period and reveals the average relationship between or among the financial ratios. The positive and high degree relationship reflects the positivity and favorable responses of working on equity or high debt-equity ratio while low degree correlation is the indication of poor influence of financial structure on other dependent variables. The negative and high degree correlation reflects the bad impact of debt-equity ratio on other dependent financial ratios while low degree negative correlation is the indication of unavailability of financial structure's impact on other financial indication.

From Table 1, it is clear that debt-equity ratio and other dependent variables are negatively correlated except ROE. This indicates that working on equity is not beneficial in petrochemicals industry in SaudiArabia. Multiple correlations between debt equity and other dependent variables also reveal that working on equity is negative for utilization of resources and liquid funds of the organization. But, debt equity is favorable for the real owners of the petrochemicals corporation in Saudi Arabia while other dependent variables are positively correlated, except profitability (G/P R) and Return on shareholders fund (ROE).

\subsubsection{Financial Ratio Sensitivity Analysis}

Financial ratio sensitivity analysis measures the impact of quick variations in independent variables on dependent variables and establishes relationship to reveal the impact on variability of independent variables on dependent variables in a very short span of time. Positive and high degree

Table 1: Multiple correlations

\begin{tabular}{|l|c|c|c|c|c|}
\hline & D/E R & G/P R & ROA & ROE & CR \\
\hline D/E R & 1 & & & & \\
\hline G/P R & -0.423 & 1 & & & \\
\hline ROA & -0.842 & 0.227 & 1 & & \\
\hline ROE & 0.159 & -0.426 & 0.329 & 1 & \\
\hline CR & -0.442 & 0.237 & 0.613 & 0.488 & 1 \\
\hline
\end{tabular}

Source: calculated on the basis of average of financial ratios of petrochemicals companies (2004-16), as ratios given in Appendix 2. correlation between independent and dependent variables reveals that instant impact of changes in independent variables on dependent variables while low degree reflects lower sensitivity or weak impact. The negative degree correlation indicates the negative sensitivity between the variables and instant negative impact of debt-equity ratio changes on other dependent variables.

From Table 2, it is given that debt-equity ratio is affecting all dependent variables negatively except profitability of the corporations in Saudi Arabia, instantly. All the dependent variables are affecting each other, but positively.

\subsection{Interpretation}

\subsubsection{Financial Ratio Analysis}

Ratio analysis of petrochemicals companies of Saudi Arabia reveals growth debts in composition of capital structure while operational performance and utilization of resources revealing negative trends. Shareholders of the companies are enjoying benefits of working on equity. Short-term paying ability is sound while increasing debts in capital structure alarming weaker long term paying ability. Financial ratio variability and financial ratio sensitivity analysis are the relative measurement and reflect impact of capital structure on companies' financial performance.

\subsubsection{Financial Variability Analysis}

\section{Financial Ratio Variability Analysis}

Most of the companies in Saudi Arabia are working on equity and historical analysis reflecting increasing trend of working on equity (Appendix1). Profitability of the petrochemicals companies are diminishing year by year and presently the profitability is in negative form (Appendix 1). Return on assets or utilization of resources of petrochemicals industry of Saudi Arabia was satisfactory before GER (20082009) but now it is being lower (Appendix 1). Return on

Table 2: Multiple correlations

\begin{tabular}{|l|c|c|c|c|c|}
\hline & D/E R & G/P R & ROA & ROE & CR \\
\hline D/E R & 1 & & & & \\
\hline G/P R & 0.115 & 1 & & & \\
\hline ROA & -0.548 & 0.014 & 1 & & \\
\hline ROE & -0.317 & 0.054 & 0.696 & 1 & \\
\hline CR & -0.438 & 0.208 & 0.329 & 0.549 & 1 \\
\hline
\end{tabular}

Originating source: Calculated on the basis of average trend indices $\left(\mathrm{TI}_{\mathrm{CBI}}\right)$ of financial ratios of petrochemicals companies (2004-16), as given Appendix 2. 
shareholders fund or equity (ROE) is satisfactory, but fluctuating. The shareholders are getting positive returns on the investments in petrochemicals companies (Appendix 1). The liquidity status of the petrochemicals companies are satisfactory and it more than two times of liquid liabilities of the corporations, but it is an indication of blockage of funds in liquidity (Appendix 1).

\section{Financial Ratio Sensitivity Analysis}

Financial ratio sensitivity analysis of the petrochemicals companies of Saudi Arabia reflects that debt-equity ratio is affecting all the dependent variables instantly but negatively except gross profit. There is no instant and direct governance by capital structure of profitability, liquidity and utilization of resources. The relationship and variability effect of debtequity ratio on other dependent variables can be summarized as below.

From Table 3, variability and sensitivity analysis it can be concluded that in long run there is positive impact of debtequity on return on equity, and other dependent variables are negatively correlated while return on assets are extremely and adversely correlated. The long-term impact of debt-equity reveals underutilization of resources of the petrochemicals companies in Saudi Arabia. In short run, debt-equity affects gross profit positively while others (Dependent Variables) affect negatively.

\subsection{Discussions}

Saudi Arabian petrochemicals companies focus on working on equity, but there is no positive impact on profitability, return on assets and liquidity. Velnamy and Niresh (2012) explained that external funds are not very beneficial for the Saudi petrochemicals companies. Ahmad (2014), Shah (2015), Waweru and Nagugi (2014) and Sultan and Adam (2015) explained on the contrary that there is positive and strong relationship between profitability and capital structure of the business organization. In Saudi petrochemicals companies, there is a negative relationship between debt equity and profitability owing to underutilization of available resources. Venugopal and Reddy (2016) and Ashvin (2017) explained in their research papers that there is a negative relationship between debt-toequity ratio and the profitability of the business organization.

Table 3: Variability effect of Debt-equity ratio on other dependent variables (2004-16).

\begin{tabular}{|l|c|c|c|c|}
\hline Financial Ratio & G/P R & ROA & ROE & CR \\
\hline Variability & -0.423 & -0.842 & 0.159 & -0.442 \\
\hline Sensitivity & 0.115 & -0.548 & -0.317 & -0.438 \\
\hline
\end{tabular}

Debt-equity ratio of Saudi petrochemicals industry are enhancing continuously, while profitability is decreasing. Probably, some internal and external factors are responsible for the decline in the operational efficiency of petrochemicals industry.

Low demand and lower prices of petrochemical products at international level due to impacts of international treaties and agreements, global economic recession, international political instability, technological advancements are the external factors that diminish the profitability of the business organizations. Human resource, unavailability of raw material, physical resources, etc., are the constraints and internal factors responsible for the underutilization and low profitability in any business concern. Return on assets of the petrochemicals sector of Saudi Arabia is slimming down followed by profitability. There is only a positive relationship between return on equity and debt-equity ratio. The real owner of the petrochemicals companies in Saudi Arabia enjoys lower level of cost of capital than expected looking at rate of return on their investment.

But, surprisingly, liquidity of the companies is moving with the debt-equity ratio. The debt-equity ratio is not improving profitability, utilization of resources of petrochemicals companies of Saudi Arabia. So, there is a need to consider factors other than capital structure. Shubita and Alsawalhah (2012) also explained that expansion of business activities, enhancement of turnover, and other factors may be directly related to the sound profitability of the business organization. Financial ratio sensitivity analysis of Saudi petrochemicals companies reveals that there is a negative impact of debt-equity ratio in the short run except on profitability. Probably, debt-equity ratio hits profitability due to production at larger scale, fully maximum utilization of step costs or fixed cost of the business organization.

\section{Conclusion}

In this study, it is observed that the petrochemicals industry of Saudi Arabia is working on equity and trend that reflect growth of external funds in petrochemicals companies. Profitability and utilization of resources of the companies are not supporting favorable concept of working on equity of petrochemicals companies in Saudi Arabia. In the long run, the relationship between capital structure and profitability, utilization of resources, and liquidity of the companies is negative. Sensitivity analysis of the petrochemicals companies is reflecting negative impact of debt-equity ratio on utilization of resources and liquidity.

There is underutilization of resources in Saudi petrochemicals companies due to low demand and lower prices, which is the result of external factors. Probably, human resources, unavailability of raw materials, and required inputs are the causes of underutilization of the 
capacity of the petrochemicals organization. Some other factors, i.e., size of the firm, focusing on profitable streams, enhancing turnover, and controlling cost of production, comprising low-cost capital options must be considered to improve the overall performance of the petrochemicals sector in Saudi Arabia. There is a need and scope for further research to know about debt options and capacity utilization of the petrochemicals companies or neutral funds.

\section{References}

Abor, J. (2005). The effect of capital structure on profitability: an empirical analysis of listed firms in Ghana. The Journal of Risk Finance, 6(5), 438-445. DOI: 10.1108/15265940510633505

Ahmad, T. (2014). Impact of capital structure on profitability: an empirical analysis of cement sector of Pakistan. Research Journal of Finance and Accounting, 5(17), 49-54.

Ali, A., \& Haque, M. I. (2014). Ratio Analysis: A Comparative Study of National Petrochemicals Co. and Sahara Petrochemicals Co. of Saudi Arabia. International Journal of Management Academy, 2(4), 53-61.

Ali, A., \& Theeb, E. A. (2018). Financial Performance of Petrochemicals Industry in Saudi Arabia: Pre and Post Global Economic Recession. International Journal of Management Studies, 4(8), 21-29. DOI: 10.18843/ijms/v5i4(8)/03

Ashvin, R. (2017). Impact of Financial Management on Profitability: Evidences from Indian Petrochemical Sector. Indian Journal of Commerce \& Management Studies, 8(2), 4752. DOI: $10.18843 / \mathrm{ijcms} / \mathrm{v} 8 \mathrm{i} 2 / 06$

Cheng, T. Y., Li, Y.-Q., Lin, Y.-E., \& Chih, H.-H. (2020). Does the Fit of Managerial Ability with Firm Strategy Matters on Firm Performance. Journal of Asian Finance, Economics and Business, 7(4), 9-19. https://doi.org/10.13106/jafeb.2020.vol7. no4.9

Chisti, K. A., Ali, K., \& Sangmi, M. I. D. (2013). Impact of capital structure on profitability of listed companies (evidence from India). The USV Annals of Economics and Public Administration, 13(17), 183-191.

Dao, B. T. T., \& Nguyen, D. P. (2020). Determinants of Profitability in Commercial Banks in Vietnam, Malaysia and Thailand. Journal of Asian Finance, Economics and Business, 7(4), 133143. https://doi.org/10.13106/jafeb.2020.vol7.no4.133

Kumar, N. S. (2015). Capital structure and its impact on profitability. International Journal of Science, Technology \& Management, 4(2), 24-30.
Marandu, K. R., \& Sibindi, A. B. (2016). Capital structure and profitability: An empirical study of South African banks. Corporate Ownership and Control, 14(1), 8-19. DOI: 10.22495/cocv14ilp1

Nguyen, A. H., Pham, H. T., \& Nguyen, H. T. (2020). Impact of Working Capital Management on Firm's Profitability: Empirical Evidence from Vietnam. Journal of Asian Finance, Economics and Business, 7(3), 115-125. https://doi.org/10.13106/ jafeb.2020.vol7.no3.115

Nguyen, H. T., \& Nguyen, A. H. (2020). The Impact of Capital Structure on Firm Performance: Evidence from Vietnam. Journal of Asian Finance, Economics and Business, 7(4), 97-105. https://doi.org/10.13106/jafeb.2020.vol7.no4.97

Nasimi A. N. (2016). Effect of Capital Structure on Firm Profitability: An Empirical Evidence from London, UK. Global Journal of Management and Business Research, 16(4), 8-19.

Rehman, M. Z., Khan, M. N., \& Khokhar, I. (2014). Select Financial Ratios as a Determinant of Profitability Evidence from Petrochemical Industry in Saudi Arabia. European Journal of Business and Management, 6(6), 187-196.

Shah, S. A. M. (2015). Financial Management Performance Effect on Organization Profitability. International Journal of Research in Engineering, Social Sciences, 5(4), 55-64.

Shubita, M. F., \& Alsawalhah, J. M. (2012). The relationship between capital structure and profitability. International Journal of Business and Social Science, 3(16), 104-112.

Subramaniyam, A. (2013). Capital structure and its impact on profitability: evidence from Sri Lankan listed banks. International Journal of Research in Commerce, Economics and Management, 3(12), 10-13.

Sultan, A. S., \& Adam, M. H. M. (2015). The effect of capital structure on profitability: An empirical Analysis of listed firms in Iraq. European Journal of Accounting, Auditing and Finance Research, 3(2), 61-78.

Velnamy, T., \& Aloy Niresh, J. (2012).The Relationship between Capital Structure \& Profitability. Global Journal of Management and Business Research, 12(13), 66-73.

Venugopal, M., \& Reddy, M. R. (2016). Impact of capital structure on firm's profitability and shareholder wealth maximization: A study of listed Indian cement companies. IOSR Journal of Business and Management, 18(4), 21-27. DOI: 10.9790/487X-1804032127

Waweru, C., \& Ngugi, K. (2014). Influence of financial management practices on the performance of micro and small enterprises in Kenya. European Journal of Business Management, 1(11), 141-161. 


\section{Appendixes}

Appendix 1: Average financial ratios of Saudi Arabian Petrochemicals companies

\begin{tabular}{|c|c|c|c|c|c|c|c|c|}
\hline \multicolumn{9}{|c|}{ Average financial ratios } \\
\hline \multirow[b]{2}{*}{ Ratio } & \multirow[b]{2}{*}{ Years } & \multicolumn{7}{|c|}{ Petrochemicals Company } \\
\hline & & Nama & SAFCO. & SABIC & TASNEE & Sipchem & SIIG & Industry Average \\
\hline \multirow{3}{*}{ Debt- equity ratio } & 2004-07 & 0.55 & 0.35 & 0.72 & 1.24 & 0.88 & 0.49 & 0.70 \\
\hline & $2010-13$ & 0.79 & 0.15 & 0.75 & 1.35 & 1.12 & 1.53 & 0.95 \\
\hline & 2014-16 & 2.24 & 0.17 & 0.56 & 2.00 & 1.19 & 1.15 & 1.22 \\
\hline \multirow{3}{*}{ Gross profit ratio } & 2004-07 & 14.43 & 60.39 & 40.00 & 32.33 & 255.30 & 36.23 & 92.52 \\
\hline & $2010-13$ & 10.46 & 71.47 & 30.67 & 30.42 & 75.03 & -0.59 & 51.90 \\
\hline & 2014-16 & -57.04 & 54.83 & 29.03 & 20.71 & -610.84 & 29.86 & -88.91 \\
\hline \multirow{3}{*}{ ROA } & 2004-07 & 1.05 & 19.38 & 12.61 & 4.73 & 6.39 & 14.36 & 9.75 \\
\hline & 2010-13 & -2.49 & 39.59 & 8.34 & 4.22 & 4.24 & 2.61 & 9.42 \\
\hline & 2014-16 & -19.15 & 24.34 & 6.81 & 0.61 & 2.92 & 6.31 & 3.64 \\
\hline \multirow{3}{*}{ ROE } & 2004-07 & 85.39 & 24.89 & 29.04 & 15.51 & 14.54 & 20.22 & 32.02 \\
\hline & 2010-13 & 246.82 & 44.32 & 17.99 & 15.62 & 10.40 & 9.03 & 57.36 \\
\hline & 2014-16 & 219.73 & 27.85 & 12.33 & -2.02 & 5.44 & 10.18 & 45.58 \\
\hline \multirow{3}{*}{ Current ratio } & 2004-07 & 0.93 & 3.02 & 2.79 & 2.37 & 3.37 & 4.22 & 2.78 \\
\hline & 2010-13 & 0.46 & 6.54 & 2.89 & 2.01 & 3.20 & 3.24 & 3.06 \\
\hline & 2014-16 & 0.93 & 3.57 & 2.80 & 1.68 & 2.06 & 2.18 & 2.21 \\
\hline
\end{tabular}

Originating Source: Financial ratios calculated from the financial data obtained from the websites of petrochemical companies.

Appendix 2: Calculation of trend indices of financial ratios based on chain based index numbers $\left(\mathrm{TI}_{\mathrm{CBI}}\right)$

\begin{tabular}{|c|c|c|c|c|c|c|c|c|c|c|}
\hline Years & $\begin{array}{c}\text { Debt } \\
\text { equity }\end{array}$ & CBI & $\begin{array}{c}\text { Gross } \\
\text { profit }\end{array}$ & CBI & ROA & CBI & ROE & CBI & CR & CBI \\
\hline 2004 & 0.63 & 100.00 & 87.91 & 100.00 & 8.51 & 100.00 & 25.77 & 100.00 & 2.01 & 100.00 \\
\hline 2005 & 0.60 & 94.96 & 76.07 & 86.53 & 10.55 & 123.98 & 30.13 & 116.92 & 3.30 & 164.41 \\
\hline 2006 & 0.58 & 97.20 & 70.93 & 93.24 & 10.31 & 97.67 & 33.00 & 109.52 & 2.77 & 83.98 \\
\hline 2007 & 0.93 & 159.88 & 66.82 & 94.20 & 10.27 & 99.66 & 39.21 & 118.82 & 2.27 & 81.99 \\
\hline 2010 & 0.90 & 96.91 & 46.57 & 69.69 & 9.79 & 95.28 & 58.04 & 148.04 & 3.10 & 136.28 \\
\hline 2011 & 0.92 & 102.08 & 103.84 & 222.99 & 9.68 & 98.88 & 58.51 & 100.81 & 3.56 & 114.88 \\
\hline 2012 & 0.95 & 103.28 & -63.13 & -60.80 & 9.69 & 100.14 & 59.16 & 101.11 & 3.02 & 84.72 \\
\hline 2013 & 1.01 & 106.27 & 57.70 & -91.40 & 8.52 & 87.96 & 53.75 & 90.85 & 2.56 & 84.89 \\
\hline 2014 & 0.99 & 97.57 & -173.79 & -301.19 & 9.17 & 107.55 & 61.15 & 113.78 & 2.66 & 103.71 \\
\hline 2015 & 1.09 & 110.68 & -82.50 & 47.47 & 5.73 & 62.52 & 46.49 & 76.03 & 2.09 & 78.88 \\
\hline 2016 & 1.58 & 144.85 & -10.44 & 12.65 & -3.98 & -69.38 & 29.11 & 62.61 & 1.87 & 89.08 \\
\hline
\end{tabular}

Originating source: Chain based Index numbers calculated from average of financial ratios of petrochemical companies. 